\title{
Regional Women's Economic Participation: A Systematic-based Review of Structural Economic Transformation in Indonesia
}

\author{
Endah Prihatiningtyastuti ${ }^{1^{*}}$ \\ 1 Curtin University, Australia; e-mail: endah.prihatin@postgrad.curtin.edu.au \\ * Correspondence
}

Received: 2020-12-01; Accepted: 2020-12-30; Published: 2020-12-30

\begin{abstract}
This article draws upon available works of literature to argue that the regional women's economic participation in structural economic transformation in Indonesia has been challenged continuously by cultural and structural factors. This reviewed article aims at providing several scientific publications on a related topic to map the available sources in understanding the contribution of women in the economic sector as well as the challenges they faced. This review paper employs a qualitative method with a systematic review of certain works related to women's participation in the economic sector. This review paper aims to provide a conceptual framework and navigation for further research conducted in a related field study. This article also synthesising an overview of the current study. By analysing reports, statistics, and prior works on this women's participation and transition into formal employment issues, this article finds Indonesian women are still less involved in the labour force and labour market than men. Socio-cultural and structural barriers contribute to the low participation of women in the economy. Such barriers include career interruption of childbirth and childcare responsibility, less education and skills, care services that the women involved considered secondary, low wage, unsupported gender-based regulations, and low support to gender equality.
\end{abstract}

Keywords: Economy; gender; labour; regional; women.

Abstrak: Artikel ini menjelaskan tentang partisipasi ekonomi perempuan di tingkat daerah dalam kerangka transformasi ekonomi struktural di Indonesia. Artikel ini berargumen bahwa partisipasi perempuan dalam bidang ekonomi dipengaruhi oleh faktor budaya dan struktural. Artikel review ini bertujuan untuk menyajikan beberapa publikasi ilmiah tentang topik terkait untuk memetakan sumber-sumber yang tersedia dalam memahami kontribusi perempuan di sektor ekonomi serta tantangan yang mereka hadapi. Artikel ini menggunakan metode kualitatif dengan tinjauan sistematis terhadap karya-karya tertentu yang terkait dengan partisipasi perempuan di sektor ekonomi. Artikel review ini bertujuan untuk memberikan kerangka kerja konseptual dan navigasi untuk penelitian lebih lanjut yang dilakukan dalam studi terkait. Dengan menganalisis beberapa kajian dan publikasi sebelumnya tentang partisipasi perempuan mulai dari masa transisi ke pekerjaan formal, artikel ini menemukan bahwa perempuan Indonesia masih kurang terlibat dalam kiprah ekonimi dan pasar kerja dibandingkan laki-laki. Hambatan sosial budaya dan struktural berkontribusi pada rendahnya partisipasi perempuan dalam perekonomian. Hambatan tersebut di antaranya adalah berkaitan dengan stereotipe yang diatributkan kepada perempuan yakni gangguan karir seperti melahirkan dan tanggung jawab pengasuhan anak, kurangnya pendidikan dan keterampilan, upah rendah, peraturan-peraturan hukum yang tidak berbasis gender, dan rendahnya dukungan terhadap kesetaraan gender.

Kata Kunci: Daerah; ekonomi; gender; kerja; perempuan. 


\section{Introduction}

This article draws upon available literature to argue that the regional women's participation in structural economic transformation in Indonesia has been challenged continuously by cultural and structural factors. Although women in Indonesia have often relatively economically productive, the patriarchal attitude leads to universal belief and promotion of the 'ideal women' as wife and mother to assign the care of family and household as women's responsibility and limited social infrastructure. This argument is supported by research analysis conducted by Cameron et.al. (2019) who found a similar report that social norms and current policies prevent the growth of women's participation in the economic sector.

The broad structural trend in the Indonesian economy is one of transitioning from agriculture to services, from low value-added to high value-added sectors. This transition brings with its gross domestic product (GDP) and income growth, and a reduction in levels of poverty (Schaner \& Das, 2016). The services sector is the fastest-growing sector in the Indonesian economy (Brockman, 2014). Further consequences of the longer-term growth in the marketplace are declining fertility rates and increasing participation in post-secondary education (Badan Pusat Statistik, 2017).

Transitioning from working in the agricultural and industrial sectors to the service sector has had a significant impact potentially on the women's economic participation, in particular, on their earnings and working conditions. This article examines the consequences for women from regional areas transitioning from the agricultural and industrial sectors to the service sector; whether women face similar situations to men, or whether they face obstacles to active participation and equal opportunity as compared to men. This reviewed article aims at providing several scientific publications on a related topic to map the available sources in understanding the contribution of women in the economic sector as well as the challenges they faced. The review is divided into three parts. The first part, located on the discussion of Indonesia's political economy and its implication to women labour participation in Indonesia. This section illustrates that Indonesia has achieved significant growth in per-capita income and a reduction in the poverty rate. But, the participation rate of women in the labour force has remained stagnant.

The second part presents a legal and regulatory deal with women and their implementation at a national level. This section performs that Indonesia's legal and regulatory framework gives limited attention to women's economic empowerment. Some laws are reflected gender-neutral and discriminatory toward women. The third section investigates the social norm as state gender ideology, ethnic culture, and interpretation of religious teaching that constraint women's economic empowerment. This section depicts that the primary of social norms that manifest in gender beliefs about the role of men as breadwinner and women as a family and home caretaker plays a significant role as a barrier for women's economic empowerment. The fourth section explores women's access to education and skill training. This section explains that women face multiple barriers to accessing education and skills training. And, following the fifth section describes the subjective autonomy and collective voice and representation. This last section explains that the economic empowerment of women increases greater women's agency significantly at the household level rather than their collective autonomy.

This review paper employs a qualitative method with a systematic review of certain works related to women's participation in the economic sector. This review paper aims to provide a conceptual framework and navigation for further research conducted in a related field study. This article also synthesising an overview of the current study. The article is presented systematically to provide the bigger picture in analysing the opportunity of women in economic sectors as well as the barriers they experienced.

\section{Indonesia's Political Economy}

The growth opportunities offered by the restructuring of the Indonesian economy have been slow to translate into material gains for women., Indonesia's women's Human Development Index (HDI) 
$(66 \%)$ is lower than for men $(71,5 \%)(\mathrm{UNDP}, 2016)$. The HDI is a summary of various indicators in measuring long-term progress in the three-core dimension of human development: access to education, a long and healthy life, and a decent living standard (UNDP, 2016). More important for this discussion is, Indonesia's Gender Inequality Index (GII) value of 0.45, ranking it number 104 out of 160 countries (UNDP, 2018). GII reflects gender-based inequalities in three-dimension that includes reproductive health, economic activity, and empowerment (UNDP, 2016). The indication is by these international metrics; there is a considerable distance to go towards gender equality in the economic and civic domains.

Growing service sectors such as home care and other hospitality services in urban areas have been opening up opportunities for women, particularly regional women who previously were involved in the agricultural and informal sector, to participate actively in this sector. Moreover, the development of new areas in urban places for leisure, lifestyle, and dining, as well as the latest trends of businesses using digital applications, have provided more space for regional women to participate in such service sectors. Nevertheless, the questions raised are: how have these new opportunities catered for an increasing number of women participation in such employment, and have women's skills (both practical and soft skills) been developed to address the opportunities that are made available through this economic restructuring?

\section{Women Labour Participation in Indonesia}

Indonesia has achieved significant growth in per-capita income and a reduction in the poverty rate (Minister of National Development Planning, 2017). The participation rate of women in the labour force has remained stalled at around 51\% (ILO, 2018). Increasing women's labour participation rates has the potential to contribute to improving the country's productivity and prosperity (Suwarno, 2019). According to Australia Indonesia Partnership for Economic Governance (AIPEG) an increase in female labour force participation to the Group of 20 (G20) target of $58.5 \%$ by 2025 would contribute $0.67 \%$ to annual GDP growth, equal to an increase in GDP of 123 billion, or the US $\$ 432$ per capita in 2025 (Cameron et al., 2019; Sitepu, 2017).

Male and female employment has shifted out of agriculture and into manufacturing and services, and this has resulted in improving social status, employment conditions, and wages (Booth, 2016; Matsumomoto, 2016). Schaner and Das (Schaner \& Das, 2016) and Matsumoto (2016) suggest that young educated women in urban areas have improved their participation in formal wage employment. However, in the case of female employment, the shift has been accompanied by an increase in vulnerable work in the services sector (Matsumomoto, 2016).

Matsumoto (2016) investigated the trend of female employment from 1996-2012 and classified three population groups of women: young women (15-24); women of prime working age (25-54); and older women (55+). Her study found that structural changes existed particularly in young women's employment status from agricultural employment to urban employment, and female employment responded more positively to fundamental change than a male job. In contrast, the statistics revealed that rural women had limited participation in the formal labour market due to working in informal employment (Schaner \& Das, 2016).

In terms of employment, the broad gender differences that are noted by the ILO (ILO, 2013) are 1) The high share of females in informal employment $(62 \% \mathrm{v} .58 \%)$ - for females this represents unpaid family workers, for males, it is own account (self-employed) workers, 2) The high share of females who are unpaid family helpers (33\% v. $7 \%), 3$ ) The high percentage of males who are employers $(29 \% \mathrm{v}$. $14 \%), 4)$ The higher rate of female employees who are low wage workers (35\% v. 30\%), 5) Despite declining through time, the gender wage gap is relatively large at around $20 \%$

Limited studies that discuss female labour participation in Indonesia (Alisjahbana \& Manning, 2006; Cameron et al., 2019; Comola \& De Mello, 2009; Schaner \& Das, 2016). Career interruption, industry employment changes, and disparity of education and skills development contribute to the lower female labour force participation rates as compared to men (Cameron et al., 2019). Career interruption is an essential barrier to female labour force participation (Cameron et al., 2019; Schaner \& 
Das, 2016; Indrasari Tjandraningsih, 2000). Childcare responsibilities are enough of an obstacle to women's engagement in the labour market (Cameron et al., 2019; Halim, Johnson, \& Perova, 2017; Schaner \& Das, 2016). For women who come back to work, childcare barriers are linked with a shift into less profitable occupations (Halim et al., 2017). After giving birth, women with no access to informal childcare are higher likely to move into, and stay in, unpaid family work. These transitions are connected with US\$255 and US\$319 in earlier receiving payment in urban and rural areas, successively (Halim et al., 2017). Halim and his friends estimate more previous earnings as the gap in median income per year in manufacturing and median income in farming or sales for women of peak age for first giving birth between 22 - 24 years old utilising the Labor Force Survey (LFS) (Halim et al., 2017).

The second challenge to female labour force participation is that the transition of women's employment from rural agriculture to manufacturing and (care) service sectors in urban areas provides few opportunities for less educated and unskilled women from the rural areas (Matsumoto, 2016). In the last two decades, the demand for employment is improving in the care sector. Women from regional areas migrate to urban and even overseas. They work as domestic workers, baby sitter, nanny, elderly care, and home health care (Dhewy, 2018). In a market economic context, care services are often viewed as not productive work to contribute to a family income or commercial society (Dhewy, 2018). As a result, care services are often turned over to household management. Another consequence, care work in general determined as unpaid work, less paid work, less secure work. Also, care services are employed under poor conditions, with low wages and few protections, even vulnerability to exploitation or sexual harassment from care service providers or recruitment agencies (Platt, 2018; Pyle, 2006; Tandos, 2017).

Despite the growing economy and the structural changes to the economy, females, in general, have a high incidence of employment in the informal sector and positions of unpaid labour (Schaner \& Das, 2016). According to the Indonesian national labour force survey (Survei Angkatan Kerja Nasional/Sakernas), the number of women in the informal sector is higher (61.37\%) than their counterpart that is only 54.34\% (Badan Pusat Statistik, 2011). Besides, there is a high incidence of employment in low-paid and insecure jobs. Regarding data from Sakernas (2017), the percentage of women employed in insecure work $(62.22 \%)$ is also greater than men $(55.10 \%)$ in 2015 . To understand how does Indonesia's governance address the high incidence of women in low-wage and insecure jobs? So, the following section will describe how legal and regulatory deal with women that could play as opportunities and obstacles factors for exercising women's agency in regional Indonesia experience in accessing formal work in care sectors?

\section{Legal and Regulatory Deal with Women and Their Implementation at National Level}

Indonesia's legal and regulatory framework gives a lack of attention to women's economic empowerment. Even though it has been more than three-decade after Indonesia ratified the UN Convention on the Elimination of all Forms of Discrimination (CEDAW) in 1984 and two decades after democratisation in 1998 (Ford, 2018), some laws are reflected gender-neutral and even discriminatory toward women.

There is no reference specifically to women in either a positive and negative manner in Indonesia's Constitution. However, some articles in Indonesia's Constitution encourage gender equality. Such as, article 27 mentions that the right of all citizen to work and a decent living, and clause 28 mentions All citizen entitled to be free from any form of discrimination (Indonesia's Constitution, 1945). Indonesia does not have yet a particular law on gender equality (Ford, 2018).

There is a lesser power regulation that promotes gender equality, for instance, Presidential Instruction No. 9/2000 on Gender mainstreaming in National Development. Post-Suharto era governments adopted gender mainstreaming strategies. President B.J. Habibie, Suharto's successor, introduced democratic values, as did the next president, Abdurrahman Wahid (1999-2000), who preferred to implement pluralist rather than absolute values (JICA, 2011). Wahid's Presidential Decree No. 9/2000 promoted gender mainstreaming to achieve equity, democratisation, and good governance, 
as integrated into national and regional development planning documents. The Indonesian government has tried to strengthen power regulation by proposing the draft bill on Gender Equality to the House Representative Council (DPR) and the Regional Representative Council (DPD) (Ford, 2018; Gender Institute, 2013). However, debate on the issues regarding gender equality has continued and wasted away since 2012 (Ford, 2018; Gender Institute, 2013).

The introduction of decentralisation has two faces and gives double side effects. On one side, moves towards decentralisation from the authoritarian period may offer higher democratic power to women. As the new system of regional autonomy has the potential to provide more excellent, and closer service delivery to the citizen include women (Noerdin, Aripurnama, \& Muchtar, 2007). For instance, decentralisation in Jembrana, Yogyakarta, Bantul, and Kulon Progo has allowed their district to increase subsidies for essential health services for low-income women (Noerdin et al., 2007). Furthermore, some local government has started to view women as a vital development subject and actively encourage women's participation in the decision making the process for resource distribution (Asian Development Bank, 2006).

However, it has also enhanced the potential for a share of discriminatory regulation that has a reduced impact on women (Ford, 2018). Conservative religious interpretation of gender roles has also accompanied decentralisation process (Asian Development Bank, 2006). Some regions have continued to propose and stipulated regional regulations that are aimed at monitoring and delimiting women's movement (Noerdin et al., 2007; Siahaan, 2003; Utomo, 2012). Some local regulations in West Kutai and Gianyar have denied the role of women in public space since local society do not consider women as breadwinners, lead to the loss of women's sources of income (Noerdin et al., 2007).

To date, Nawacita is nine national visions of the Indonesian government (2014-2019) taken by President Joko Widodo, includes 1) Bring back the state to its duty of protecting the security of all citizens; 2) Building clean, effective, and democratic, trusted governance; 3) Developing Indonesia on the outskirts through the strengthening of the regions and villages within the framework of the unitary state; 4) Reforming the legal system and law enforcement, which is corruption free, dignified, and trusted; 5) Enhancing the quality of human life through the enhancement education and training; 6) Improving productivity and competitiveness in the global market to strengthen Indonesia's position among Asian nations; 7) Attaining economy independence within mobilising strategic national of economic sectors; 8) Revolutionising the character of the country by revising the national curriculum which emphasise citizenship education; 9) Strengthening "The Unity in Diversity" and encouraging social restoration by increasing diversity education and providing space for citizens' dialogue (Minister of National Development Planning, 2017).

Nawacita, as a priority agenda of Indonesia, is a national aspiration to achieve a sovereign, independent, and characterised nation by implementing cooperation (Kompas, 2014). That vision faces significant development barriers, for instance, poor people, inequality across the region, and income groups (Kompas, 2014). The Jokowi government has continued on a financial inclusion strategy developed by the government of his precursor to decrease growing income inequality by improving access to saving, credit, and insurance; to transfer facilities, by giving financial education and the providing of a business identity number; by enhancing the regulatory of the environment (Presiden Republik Indonesia, 2020). However, Nawacita's vision is expressed in the gender-neutral term (Ford, 2018). The Nawacita does also not include a specific focus on women in the strategy for financial inclusion reflects a greater reluctant of the government's commitment to supporting gender equality (Ford, 2018).

The neutral policy above does not imply, however, that there has been no advancement on gender achievement in the present government. The newest policy initiatives introduce gender equality goals, such as the National Medium Term Development Plan (RPJMN) 2015-2019, which adopts the Sustainable Development Goal targets (Ford, 2018). This plan is explicitly described to increase women's role and representation in political and economic development. To date, the policy of gender mainstreaming and various women-focus initiatives have continued which includes the Gender Responsive Budgeting (GRB) policy and the flagship 3Ends program which have been initiated by the 
Ministry of Women Empowerment and Child Protection (Ford, 2018). The national strategy implements the acceleration of gender mainstreaming through the Gender Responsive Budgeting policy which is led by the Ministry of National Developing Planning, intended to assist in achieving those targets (Ford, 2018). GRB focuses on gender issues such as women's disproportionate responsibility for unpaid work and the distribution of resources within and between families, in budget analysis and decision making to reduce gender inequality (Diane Elson \& Sharp, 2010). The 3Ends program has three aims: to end violence against women, trafficking of women and girls, and economic justice for women through improving access to finance and training (Ford, 2018). The current policies depict the advancement of national commitment to support women's participation in the formal sector workforce. However, the progress of women's economic participation remains slow as a result of cultural and structural barriers (Ford, 2018).

According to Ford (Ford, 2018), Indonesian men and women are not discriminatory by Indonesia's legal system concerning access to employment, and its conditions such as the right to work; equal pay; equal opportunity/freedom from not treated differently; maternal, reproductive, and childcare right. The right to work, to strengthen that what noted in Indonesia's Constitution 1945, the Indonesian government has stipulated article 38 of law No. 39/1999 on Human Rights mentions that all citizens have the right to work and the right to free selection of employment and just situations of work. Furthermore, article 49 of the law further ensures that women have the right to choose, be chosen and appointed to a proper job, position, or a profession and the right to special protection in the business of work or professional that could request her safety and her reproductive health hazard. Equal pay is also guaranteed in Law no. 39/1999 on Human Rights and strengthen by Government Regulation no. $78 / 2015$ on pay decree that employee has the right to equal pay for similar categories of work. Also, Article 5 and 6 of Law no 13/2003 on Manpower ensures the right to equal handling during the recruitment and equal handling from employers. Besides, Manpower Regulation No. Per-03/Men/1989 prohibits employers from dismissing women based on marriage, pregnancy, and giving birth. Regarding reproductive role, Law no.13/2003 ensures the women's right to three months paid maternity leave in the period of childbirth and to six weeks paid leave for the women who endure miscarriage.

The quality of women's lives has improved in several sectors, such as health, education, economics, and politics (Blackburn, 2004; Ford \& Parker, 2008; Robinson, 2008). The macro measurements of development perform the growth of human quality lives such as the improving Human Development Index ${ }^{1}$ (HDI) and the Gender-Related Development Index ${ }^{2}$ (GDI) from 2017 to 2018, and the Gender Empowerment Measurement ${ }^{3}$ (GEM) in 2018. For instance, according to Badan Pusat Statistik (BPS) or National Statistic Agency, Indonesian HDI increased from 70.81 in 2017 to 71.39 in 2018 (BPS, 2018). Similarly, the Indonesian GDI rose from 68.08 in 2017 to 68.63 in 2018 (Badan Pusat Statistik, 2018). The Indonesian GEM increased from 71.74 in 2017 to 72.10 in 2018 (Badan Pusat Statistik, 2018).

Through this section, the study examines how does the existing gender empowerment index considers women's agency and economic empowerment as they transition from informal work in the primary industry of agriculture to formal employment in non-agricultural sectors? Firstly, referring to Cueva Beteta's argumentation (2006) that GEM is not a complete and biased index to measure women's empowerment. Although the GEM integrates women's empowerment in the public sphere, the GEM indicator only focuses on measuring the most educated and economically advantaged. Furthermore, the GEM also does not involve significant non-economic dimensions of decision-making power on the

${ }^{1}$ Human Development Index is the measurement assessed by measuring length of attendance at school, life expectancy, and income generated (UNDP, 2016).

2 Gender Development Index is the measurement which assesses gender differences in human development. The measurement accounts for disparities between men and women in health, education, and living standards (UNDP, 2016).

3 Gender Empowerment Measurement is the measurement which assesses using women as representatives in Parliament, the number of professional women, women's income- generating history (UNDP, 2016). 
individual or private (such as women's owned body and sexuality) and at the household level (Cueva Beteta, 2006). In practice, policymakers often use the UNDP gender empowerment measure (GEM) data for determining policies or making decisions about gender inequality and women's empowerment across regions and over time (Kabeer, 1999; Schüler, 2006). It seems that the way of Indonesia's gender experts and policymakers still utilise stereotypical approaches and generalisations when developing solutions to address women's segregation and exclusion in the labour market.

In specific contexts of women empowerment measurement, Borrowing Cueva Beteta's idea (Cueva Beteta, 2006), the study criticises the way of Indonesian gender expert and policymaker evaluate the indicator of women's political power is not include the percentage of women representative in local government, rather than only focus on the rate of seats held by women in the national parliament. Secondly, it is only applied a measurement that more responsive toward the more significant economically advantaged population. Thirdly, the current GEM does not describe an indicator of women's decision making power at the individual and household level. Fourth, the GEM does not involve societal attitudes toward the equal right of men and women to education, be political leaders, have economic power. Fifth, the GEM does not include the information about the strength of the women's movement and legal or regulatory instrument that is enabling women's empowerment.

Secondly, in terms of the care economy, gender experts and policymakers in Indonesia consider either GDI and GEM measurement only to measure and explain "universal breadwinner" women's participation in formal employment and decision making position (Folbre, 2006). Rather than promote increased women paid employment by encouraging and cooperating both men and women to associate paid work and family care (Folbre, 2006). Indonesian governance only capturing the outcome of care through improved health, education attainment, employment participation. They do not concern with a better measure of input into care that primarily sends most responsible to women (Folbre, 2006).

In the latest news, President Joko Widodo raised issues focusing on access to education and women's empowerment in his speech at the 3rd Session of G20 in Osaka on 29th June 2019. He also said about the urgency of adjusting the new education system that is still using the prior pattern (Cabinet Secretariat, 2019). Later, he emphasised his vision to develop the nation's human capital with the slogan "Superior human resources, Indonesia Onward" in his annual speech one day before Indonesia Independence day (Presiden Republik Indonesia, 2019). To respond to his political will, the Indonesian government under President Jokowi will take human resources development as one of some priorities in the next five years (2020-2024) as his second period elected (Presiden Republik Indonesia, 2019). Nevertheless, the questions raised are: how has this new goodwill of the Indonesian president interpreted and implemented by the regional government for an increasing number of women's participation in such employment? And which institutions have the responsibility for women's economic empowerment?

\section{The institutional responsibility for women's economic empowerment}

The central state institutions hold responsible for women's economic empowerment is the Ministry for Women's Empowerment and Child Protection which coordinate within the Coordination Ministry of Human Development and Culture, the Ministry for Development Planning, the Ministry of Finance, and the Ministry of Manpower.

The Ministry of Women Empowerment and Child Protection (MOWE) is the crucial body for gender equality achievement and women empowerment through the implementation of gender mainstreaming. MOWE is the institution that works to coordinate and encourage gender-responsive planning and budgeting at national and regional development. Also, the Coordinating Ministry of Human Development and Culture holds a responsibility to synchronise policy planning, formulation, and implementation for issues relevant to human development and culture. The Ministry for National Development Planning (BAPPENAS) is the institution that plays a crucial role in inserting and gender mainstreaming perspectives into Indonesia's development blueprint document (Diane Elson \& Sharp, 2010). In the following step, the Ministry of Finance also play a key role as a driver institution which encourages gender-responsive budgeting and taxation, and in gender and financial inclusion (Diane 
Elson \& Sharp, 2010). The Ministry of Manpower holds responsibility for formulating, implementing, and supervising the workforce, labour standards, and industrial relations of policies that affect women's wellbeing status, involving social security, welfare, and the women labour protection of reproductive rights and workplace discrimination (Ford, 2018).

Social norm as state gender ideology, ethnic culture, and religious interpretation that constraint women's economic empowerment

The sequent government has promoted women to presume productive and reproductive roles (Ford, 2018). According to Moser's study (Moser, 1994), the productive role is determined as "work done by both men and women for pay in cash or kind. It includes both market production with an exchange-value, and subsistence/home production with actual use-value, and also potential exchangevalue." However, women's participation in productive works is usually interrupted by the reproductive role associated with family care (OHCHR, 2014).

However, The primary social norms that manifest in gender beliefs about the role of men and women constrain women's economic empowerment (Ford, 2018). Social norm, as reflected in Indonesian state gender ideology which portrays a strict demarcation between an image of $I b u$ (mother) and Bapak (father) and maintains to command that women (as wives, mothers, and daughters) stay priority dedicated to looking after for their husband, children, and parents (DjajadiningratNieuwenhuis, 1987; Ford, 2018). The way of socio norms produces a division of labor is opposite to the former ideas of citizenship in the country. In article 31 of the 1945 Constitution of the Republic of Indonesia, recognise men and women as citizens, with equal rights, tasks, and responsibilities, but the former Suharto's New Order encouraged the idea of what Suryakusuma identifies as 'State Ibuism' (Suryakusuma, 2011). In general, society assumes that women as wives, mothers, and servants whose lives are constructed by state gender ideology and regulated employing government intervention. The Indonesian Marriage Law No. 1 of 1974 which assigns women as householders and men are as heads of households and breadwinners, hands men a prerogative in economic, social, and political activities while women are responsible for family life (Robinson, 2008).

The enduring hegemony of patriarchal ideology blends not only with state gender ideology but also ethnic and cultural traditions. For instance, Javanese culture maintains a gender hierarchy by establishing an ideology of familial, which emphasises the women's primary roles in the domestic sphere as wives and mothers (Kusujiarti, 1997). Men are not expected to take part in household tasks, as this is not their natural domain. They have time to be involved in the civic and public activities that are closely associated with status and power, while women must wrestle with household responsibilities before they can take on other tasks.

The makeup of the Javanese cultural, social, and economic structure constrains women in Java from being autonomous in their mobility in public space. In Javanese culture, the traditional feminine ideal of being submissive and obedient limits the chance of a woman being independent (Hayati, Högberg, Hakimi, Ellsberg, \& Emmelin, 2011). The necessity of women's obedience is reflected in the Javanese saying "Swarga nunut nraka katut," meaning that whether men go to heaven or hell, the wife will follow her husband (Hayati et al., 2011; Hermawati, 2007). Although it is assumed and expected that men should respect their woman's managerial position and authority in her household (White \& Hastuti, 1980), Javanese men very often act as a master or the boss of the Javanese household (N. Sullivan, 1994), thus usurping her power. Sullivan also indicates that Javanese ethnic culture does not admit women's managerial authority in reality, nor does it carry any authority outside the home (N. Sullivan, 1994).

Hildred Geertz (1961) highlighted hormat and rukun as two paramount values in Javanese culture, crucial to maintaining a harmonious life. Hormat, or the notion of respect, is honoured both in family interactions and also as a social norm between neighbors or to government officials (Geertz, 1961). This emotional understanding of respect is passed through generations to achieve and preserve social harmony. These traditional values still exist in contemporary Javanese society. However, Javanese culture does not promote mutual respect (reciprocity) among people of different age, sex, occupation, 
or wealth. The social 'inferior' (child, woman, peasant, low-income people) should respect their 'superior' (parent, man, aristocrat, wealthy individuals). But the superior does not need to give as much respect in return to the inferior (Geertz, 1961).

Religious interpretations in Indonesia strengthen the cultural norm that assigns women to the domestic space (Prihatiningtyastuti, 2018). The religious attitudes towards the position of women's participation in public life are important to be included as barrier factors faced in Indonesia. It contributed to the majority of opinion that the role of women ideally are at home and it is men's responsibility as an income earner. The views of local culture and understanding and practices of Islam as a majority religion of Indonesia's population, which attribute the responsibility of productive and reproductive works to women perpetuates women's vulnerable position (Prihatiningtyastuti, 2018). The views of women's rights in Islam focused surround the central passage from Surah An Nisa'34, The Qur'an, which is cited in the Muslim world includes Indonesia to reflect women's subordinate status to men. The passages mentions:

Men are the protectors and maintainers of women (Quwamun) of women, because Allah has given the one [men] more (strength) than the other [women], therefore, the righteous women are devoutely obedient, and guard in (the husband's) absence what Allah would have them guard. As to those women on whose part ye fear disloyalty and ill-conduct, admonish them (first), (next), refuse to share their beds, (and last) chastise [daraba] them (lightly); but if they return to obedience, seek not against them means (of annoyance): for Allah is Most High, Great (above you all).

There is the broad diversity of the Muslim world, with its various levels of faithfulness to Islamic instruction. Many parts of the Muslim believed in An- Nisa 34 to conform to men's superiority over women (Adamson, 2007; Omar, 2014). The interpretation focuses first on the terminology of qowam in this passage of verse, and second on the classical understanding of the Qur'an and Hadith (Adamson, 2007). This interpretation enforces for women in Islam into gender inequality condition both in family and national relations (Adamson, 2007; Omar, 2014). Misusing the authority of the husband as the rulers in the family is potential as a source of discrimination against women, the violation of women's rights, poverty, and unemployment (Omar, 2014).

In contrast, the contemporary Muslim feminists argue that patriarchal reading and historical bias generate this misinterpretation (Omar, 2014). The feminist Muslim consider men to "protector, and maintainer" rather than "rulers" over family members in full context (Omar, 2014). According to feminist Muslims, leadership in Islam is about responsibility and accountability rather than merely about authority. The men who took care of this trust (women and family members) will be accountable for God Almighty on the Day of Judgment (Omar, 2014).

The first socio-cultural norms that interpretation of religious text includes teaching produce gender belief about the role of men and women both in families as well as in the society constraint women's economic empowerment (Ford, 2018). Patriarchal socio-cultural norms that delegate women (as wife, mothers, and daughter) should act as the primary labor to care for their spouse, children, and parents in daily practice (Ford, 2018; Robinson, 2008; Utomo, 2012). In Indonesia rapid modernisation, the gender belief, as reflected in state gender ideology which subsequently interpretants into policy framework and programs has little changed over the last several decades and continued to constrain women's economic empowerment within the assignment of unpaid care work (Ford, 2018; Utomo, 2012).

\section{The Implication of Patriarchal socio-cultural norms to Women's Economic Participation}

The hegemony of patriarchal norms still dictates Indonesian society to see women's employment as a secondary earner (Ford, 2018; Utomo, 2012). Utomo surveyed senior university students both in Makasar as well as Jakarta in 2004. The finding result depicts that neo-traditional beliefs of middle class still reflect men as a breadwinner, and women as a secondary earner (Utomo, 2012). Sohn (2015) examined data from the 2007 Indonesia Family Life Survey to reveal the gender gap in earning in paid work and self-employment. The finding research shows that men made about $70 \%$ greater than women 
(Sohn, 2015). From this primary evidence, Sohn (Sohn, 2015) speculates that cultural, religious, and social norms in Indonesia drive high discrimination against low-earning women in paid employment. This injustice treatment may be produced by employers who perceive that women are less fixed than men to the labour market, so these employers provide higher chances for earnings growth, to men than to women. Therefore, women are often seen as a secondary earner. Even, when a woman eraned the greater contribution of family income she is likely to perceive her self and be viewed by others- as second earner (Ford, 2017).

Women employment often select roles that will enable them to accommodate their family duties, which affect their being drop out of waged work as well or leadership (Nilan, 2008; Utomo, 2012). The lack of flexible workplace practiced for paid, and professional women employment effect women who prefer to move their role that allows higher flexibility but has less leadership chance that familiar known as career interruption (Schaner \& Das, 2016). Career interruption is an essential barrier to female labour force participation (Cameron et al., 2019; Schaner \& Das, 2016; Indrasari Tjandraningsih, 2000). Childcare responsibilities are enough of an obstacle to women's engagement in the labour market (Cameron et al., 2019; Schaner \& Das, 2016).

\section{Gender Labor Division of Unpaid Care Work}

Indonesia government has nearly not provided both care infrastructure and financial assistance to a community or private sector based childcare services (Ford, 2018). Responsibility for the care in Indonesia that includes maintenance, education, and protection of children is assumed to occupy with parents, as mentioned in Law no 23/2002 on Child Protection (Ford, 2018). The revived New Order has defined the ideal woman as wife and mother, whose primary duty is to care for her husband and children, making women responsible only for domestic work rather than becoming the breadwinners who work in the public sphere (Norma Sullivan, 1991, pp. 83-84). The government offers no social security advantages for caretakers; no assistance and benefits in kind; and no incentives to stipulations in the market for the worker of assistance providers and does not stipulate the fees this assistance charge (Ford, 2018). Thus, unsatisfied children care interest plays as a constraint for some women, then drives to low women labor force participation in Indonesia (Halim et al., 2017). Halim and his colleagues' research finds the maximum amount of household might be willing to pay for children care services is not higher than US\$650/year. They predict the maximum readiness to give payment for childcare services utilising data on earnings. If able to sustain working after childbirth, urban women would likely receive US $\$ 650$ on average per year. Neither public nor private childcare services offered at the same or more significant cost would provide a viable alternative to decreasing women paid jobs (Halim et al., 2017).

To respond to global consideration to the young child, the Indonesian government has designed early childhood national and provincial projects since 2000 (Newberry, 2014). However, most development planners within patriarchal attitudes develop early-childhood education programs and then delegate women to operate them as extensions of their roles as "mothers" in the level of the state. Therefore women maintain to be determined as 'mothers' both in the private and domestic realm and in public (Blackburn, 2004). This gender designation forms the employment and experiences of women as teachers in early childhood education centers the volunteer-run child-welfare (early-childhood education) program or PAUD project provides low economic incentives and produces extra burdens for women. PAUD project is a project for children before formal school age, would be started in this lower-income society, to support children's empowerment (Newberry, 2014). This project engages women's volunteer labour in their community. Women feel forced to act because this project runs based on a parent's responsibility for children's educational interests. Thus, women's role as care labour of their family has to participate in this project (Newberry, 2014).

Eldercare is also of consideration, data from the Central Statistic Agency in 2007 stated that people older than 60 years old in Indonesia, around 8.97 percent of the total population. Also, a report from the United Nations, with the World Population Ageing, Indonesia projected that the rate of people older than 60 years old would 19.2 percent in 2050 (United Nation, 2013). There is an improving number 
of elderly Indonesian in urban are cared for in institution and professional care (Van Eeuwijk, 2006). But, predominantly, eldercare stays to take the type of informal care hold by the family and household without service, support, and guidance from professional caregivers due to limited socio-economic conditions (Van Eeuwijk, 2006). Various ethnic groups in Indonesia have a different expectancy of eldercare. However, the finding of a study by Kevane and Levine (Kevane \& Levine, 2000) shows younger daughters in their home are often responsible for caring for their aging parents.

The provision of child and elderly care extremely gendered (Ford, 2017). Women dedicate more than twice as much time to children compare to men (World Bank, 2012). Women are often disproportionally assigned to caring work not only childcare and elderly care but also health care and education (Folbre, 2008). As a result, as mentioned above, Indonesian women have a high chance of an interruption or dropping out of employment after children bearing than other nations in the region (Schaner \& Das, 2016). According to Setyonaluri (2013) in Indonesia, women job often experience dropping out or career interruption that effected by marriage and assault of motherhood.

Misunderstanding of care work brings women into marginalisation and impact on gender equality. Up to now, People often assume that care work is defined as reproductive work and has less contribution to the micro and macro economy (Sigiro, 2018). Traditionally society presumes care work is being women's responsible as gender role assigned (D. Elson, 2000). As a result, when women entrance into paid employment, they are also burdened with care work as a biologist and social reproduction role in their household (Sigiro, 2018). On the other side, the continued thought that nonproductive care work does not need highly skilled. The determination of skilled and unskilled is only education and work techniques based that women's access is limited (Matsumomoto, 2016; Sigiro, 2018). In developing countries, paid care works are very often valued with low wages and less work security such as domestic worker, baby sitter, elder sitter, home-health caregiver compare to driver and handyman that men familiar with (Sigiro, 2018). In this case, Sigiro (Sigiro, 2018) confirms Folbre's argumentation that work opportunity and wage discriminations bring women into ignoring care worker's rights and then lead to gender inequality ultimately (Folbre, 2008; Sigiro, 2018).

\section{Women's Access to Education and Skill Training}

Access to education plays a significant role in determining the level of women's labour participation (Cameron et al., 2019; Feridhanusetyawan, Aswicahyono, \& Perdana, 2001; Schaner \& Das, 2016; Suwarno, 2019; Indrasari Tjandraningsih, 2000). The remarkable probability of young women entering the labour market increases if they have a high educational background (Feridhanusetyawan et al., 2001; Schaner \& Das, 2016). Less-educated women in rural areas, thus continue to face a hard challenge when they enter into paid employment (Nansereko, 2010; Suwarno, 2019; Indrasari Tjandraningsih, 2000).

The average adult literacy rate has slightly improved from 2006 to 2016 in Indonesia. According to data from Statista in 2019, the adult literacy rate, which measures people, aged 15 and over who can read and write, shows an increase from 91.98\% in 2006 to 95.38\% in 2016. In 2006 the literacy rate of adult men (95.16\%) was higher than adult women (88.79\%). Moreover, the parity of adult literacy in $201693.59 \%$ literacy rate for adult women and $97.17 \%$ for adult men lead between women to men showed little improvement over 96.3\% (Statista, 2019).

Targeted vocational programs are one of the alternatives to elevating women's skills to obtain various job specificities. Placement services can effectively link women with skills to relevant employment opportunities (Schaner \& Das, 2016). Data from Sakernas (Badan Pusat Statistik, 2011) shows that women who have attended vocational education have more chances to gain paid jobs than women who studied conventional senior high school.

The inadequate quantity and quality of training infrastructure aggravate accessibility of lower skills development (Tambunan, 2004). Even though skills development is pivotal, particularly for needy women, who are less educated and means limited skills (Widarti, 2004), this is common in Indonesia. The restricted availability of training infrastructure types which includes the voice and choice of women on less income, who are low educated, speak only a minor/ language and live in 
remote areas stay to be problematic for women in some countries outside Indonesia and Indonesia in this case (Hartl, 2009). There is also a limited school or training centers, which could include various women's interests (Hartl, 2009; Tambunan, 2004). The training provider should accommodate women's voices as users of skills development regarding what kind of skills they want to study and how they will utilise their skills (Adams, 2011).

Even the training provider offers a mobile training unit; it is often not easy to reach out to isolated areas (Hartl, 2009). Furthermore, the time, substance, and approach of services may not be suitable to the women's interests (Tambunan, 2004) mainly if there are already low levels of education and literacy. The training provider has developed many types of training programs with a top-down approach, and a lack of an active and empowerment studying process (Hartl, 2009; Tambunan, 2004) and the policymakers are absent to acknowledge the next adverse on rural women. Appropriate material, human, and social resources are provided to increase women's ability to exercise how they can have more control over their participation in the larger society (Ford \& Parker, 2008; Kabeer, 2012)

Women are not homogeneous, and skills are multidimensional (Chowdhury, 2013). In general, women often be separated from limited qualifications, less pay, and informal employments (Dewi \& Rachmawati, 2014). Divergent backgrounds of economic class, gender, language, ethnic culture, religion, and geography create differences in women's experiences and combination of skill interests (Suwarno, 2019). Event hough vocational programs or other technical skills training might be significant for fulfilling women's practical interests to promote their role as a family income contributor, different kinds of skill training such as leadership training is essential to fulfilling women's strategic interests to overcome their subordination to men and assist them shifted from their experience of subordination (Atwell, 2006; Kabeer, 2012; Yumarni \& Amaratunga, 2015). While jobs with physical tasks require manual or technical skills, employments with more mental tasks require cognitive skills. In some cases, women also need non-cognitive and interpersonal skills to increase their control over their participation in the labour market and to expand communication as well as leadership skills (Cunningham \& Villaseñor, 2016; Kabeer, 2012).

Women require leadership and management skills training as part of non-cognitive skill training are considered fundamental to increase their agency (Debebe, 2009; Yumarni \& Amaratunga, 2015). Leadership and management skill training encourage female learners to develop attributes such as confidence and authority (Yumarni \& Amaratunga, 2015). These skills are common and have applications to the labour market and their larger societies (Debebe, 2009; Yumarni \& Amaratunga, 2015). Although women's leadership in the business sector is still problematic in Indonesia, the number of women workers involving in the informal and formal sectors have been remarkably rising. However, women are rarely in managerial positions in both the informal and formal sectors (Dewi \& Rachmawati, 2014).

\section{The Subjective Autonomy and Collective Voice and Representation}

Women gain increasing autonomy in the private sphere after they involve in economic activities (Fernandez, Della Giusta, \& Kambhampati, 2015; Yuliantini, 2018). Fernandez, together with Della Giusta, and Kambhampati examines the interconnection between agency and women's subjective wellbeing in Indonesia (Fernandez et al., 2015). They investigate the association between women's capacity to make decisions for their household (connecting to a financial decision, children, and their own leisure time) and women's subjective well-being (feeling good or happy). Their research finds that the women's agency has a strong relationship with personal well-being, even though their interconnection between agency and well-being is not straightforward. While Fernandes and his friends choose to operate a quantitative approach by analysing The Indonesia Family Life Survey, Yuliantini (Yuliantini, 2018) applies a qualitative approach with five subject women family heads in savings and loan activities to understand their subjective and collective autonomy. Yuliantini's study shows that the autonomy of women heads of household increases significantly at the household level rather than their collective autonomy. Savings and Loans microfinance program has been successful in increasing women's access to finance resource and elevate women's confidence as an individual at the family level (see further the 
article in this volume on Islamic-based microfinance). Schaner and Das (Schaner \& Das, 2016) also find similar evidence that women who participate in a paid job also come into view to be greater empowered. Higher empowered in this term means that they have a higher capacity to involve in decision making in their household and lower accepting their spousal violence.

However, back to Yuliantini's works on saving and loans microfinance, this project has not covered women's strategic needs to advance women's roles, socio-economic and political status, hierarchy in society. The limited development of women's mobility and networking in their community affects uncover women's strategic interest. So, women's subordination and marginalisation in the security networking of society is remained (Yuliantini, 2018).

Both of the resulting studies of Fernandez et al. (Fernandez et al., 2015) and Yuliantini (Yuliantini, 2018) confirm what study by John McCarthy and Greg Acciaioli (McCarthy et al., 2014) found, namely that projects to empower women in rural communities to create ambiguous outcomes. On one side they open new chances for (women) villagers to involve in development planning and obtain space for adaptive learning at the village level. On the other hand, women's decision-making capacity continues limited because of elite capture and deeply rooted social hierarchy.

Women's (economic) participation elevate potentially women's agency in various spectrums. Tjandraningsih (I. Tjandraningsih, 2018) finds the strength of women's decision-making capacity in three living spaces such as household, labor market, and organisation. Results of her analysis perform that women factory workers have various a starting point to play a pivotal gender role as a mother, worker, and activist of labor organization. There are still a few numbers of women who can practice significant gender roles in the triple activities all at once (I. Tjandraningsih, 2018). Borrowing the power concept that is offered by Linda Mayoux (Mayoux, 1998), in Indonesia, there is a more significant number of women worker who able to perform power within (increasing capacity to self-control), the power to (increasing ability to earn), power over (increasing access to resources), but still less number of women worker who can act power with (collective autonomy) (I. Tjandraningsih, 2018; Yuliantini, 2018). The stereotype of gender role in patriarchal societies in labor organisation act as a constraint for women to become a primary player in the labour movement (I. Tjandraningsih, 2018).

To date, women often experienced their limited visibility, collective voice, and decision making power in the community and nationally (Ford, 2018; Prihatiningtyastuti, 2018; Yuliantini, 2018). Legislators play a significant role in economic decision making both at the regional and national level, where they have the potential to support and prevent women's economic empowerment (Ford, 2018). The percentages of women parliamentarians have escalated from $8 \%$ to 18.6\% from 2000 to 2012, decreasing slightly to $17.1 \%$ in 2015 (World Bank, 2016), in large part as a result of the introduction of a 30\% gender quota that would stimulate women's historically low-level representation. However, the outcome was disappointing for those hoping for a quick jumpstart in the percentage of women elected in the parliament (Hillman, 2018; World Bank, 2016). There is no reward or punishment for a political party as a consequence of the accomplishment of the mandate of $30 \%$ women's quota (Adriana, N., Siregar, Haris, Yanuarti, \& Budiatri, 2012). The primary platform and regulation of political parties are still less gender-sensitive that limits an opportunity for women's cadre to take a significant role in political parties (Adriana, N. et al., 2012). The cultural aspects continue to play as the primary barrier to gender quota's potential to offer more great seats to women candidates (Hillman, 2018).

However, once women hold a seat in parliament, they still experience primary constraint in affecting policy-making because of their often subordinate and marginal status in the social structure (Adriana, N. et al., 2012). There are only a few women in parliament who have sufficient knowledge and skill to contribute to the political decision-making process and specifically in supporting prowomen policies (Adriana, N. et al., 2012). The predominantly of decision-making position is also held by men, even though women are well represented in the public sector (Budiatri, 2016; Ford, 2018). Research's Budiatri (Budiatri, 2016) finds that women parliamentarians have higher performance than men parliamentarians. However, it found also here that men parliamentarians have contributed a more significant fruitful role in the development of criminal law against human trade (UUU PTPPO) and the act of citizenship (UU Kewarganegaraan) (Budiatri, 2016). 
Women's group in Indonesia since the early 20th century has used Women's collective action to elevate women's states and welfare (Lockley, Marcoes, Nugroho, \& Boang-Manalu, 2019). This variety of backgrounds, motives exist due to the different and specific conditions and requirements of each of the women's groups in those collective actions (Lockley et al., 2019). Many Non-Government Organisations (NGO's) are involved in promoting women's economic empowerment, with a focus on issues, such as religious, culture and reproductive health (Balai Aisyiah); migrant labour and femaleheaded household (Serikat Perempuan Kepala Keluarga-PEKKA); migrant labor (Migrant Care, Indonesia Migrant Worker Union); feminist leadership and women's right (Sekolah Perempuan/Women School)(Ford, 2018; Lockley et al., 2019).

The result investigation of Lockley and her colleagues (Lockley et al., 2019) shows that gender inequality that they face in their daily lives stimulates the participation of women in collective actions. The collective action of women operates with the formal or informal formation and do an activity of groups or networks of primary women that want to lead better wellbeing in women's lives (Lockley et al., 2019). The women were empowered within the collective actions to strengthen their access not only to social services but also legal protection (Lockley et al., 2019). According to Lockley and her friends (Lockley et al., 2019), the women's collective action has empowered in focusing on five aspects such as an increasing human, economic, agency, social, and compliment capital. In this term, a growing human capital involves an improving health status, literacy, numeracy, knowledge, and skill of work, selfconfidence. The economic capital includes a capacity to access financial resources. The agency capital covers an ability to involve and influence in household and community. Social capital consists of an ability to broaden social networking. Also, the complement capital includes improving access to administrative and legal documents, as well as law protection (Lockley et al., 2019).

\section{Conclusion}

Indonesia has achieved significant growth in per-capita income and a reduction in the poverty rate. But, the participation rate of women in the labour force has remained stagnant. By analysing reports, statistics, and prior works on this women's participation and transition into formal employment issues, this article finds Indonesian women are still less involved in the labour force and labour market than men; even that women labour participation in Indonesia decreased in 2017. In other words, women are continued to have less capacity than men to exercise agency, even in Indonesia's economic growth.

Presumably, the transitioning from working in the agricultural and industrial sectors to the service sector has not resulted in a significant positive impact for women employment in the national context because of three factors. First, hegemony patriarchal attitudes that are integrated into socio-cultural norms bring into women social disadvantage. Patriarchal socio norms manifest in gender beliefs about the role of men as breadwinner and women as a family and home caretakers, play a significant role as a barrier for women's economic empowerment. Second, Indonesian men and women are not discriminatory by Indonesia's legal system about access to employment, and it's condition. But, Indonesia's legal and regulatory framework gives limited attention to women's economic empowerment. Some laws are reflected gender-neutral and discriminatory toward women. Third, women experience multiple constraints in accessing education and skills training. Fourth, the existing gender empowerment index has not considered women's agency and economic empowerment as they transition from informal work in the primary sector of agriculture to formal employment in care service industries. As a result, women's economic empowerment through labour participation does not contribute optimally to their family income and family structure and relationships. That situation above brings a similar effect to the limited women's autonomy in collective action.

The barriers may vary from region to region. Illiteracy, existing norms, and ethnic culture, lack of public infrastructure, and geographical aspects are inhibitors to women gaining education and training improvement. Different backgrounds of economic class, gender, ethnic culture, religion, and geography mean that women workers are more segregated than men workers and lead to different experiences and combination of skill needs. More research on the cases of regional women's economic participation 
is encouraged to complete information on women's agency and empowerment in a local context. Equally important is to conduct research on women's economic participation during the pandemic era and its impacts on that of woman participation.

Acknowledgment: This article is part of a progress work conducted by the author in the completion of her Ph.D. program. Thus, cross-referencing might be available following the publication.

\section{References}

Adams, A. V. (2011). The Role of Skills Development in Overcoming Social Disadvantage (No. 2012/ED/EFA/MRT/PI/04).

Adamson, C. (2007). Gendered anxieties: Islam, women's rights, and moral hierarchy in Java. Anthropological Quarterly, 5-37.

Adriana, N., S., Siregar, S., Haris, S., Yanuarti, A., \& Budiatri, L. A. (2012). Women's representation in Parliament "The Performance of Women Legislator: Measuring the Contribution of Multi-Party System Toward The Women's Political Participation in Indonesia." Jakarta: Lembaga Ilmu Pengetahuan Indonesia and Konrad Adenauer Stiftung.

Alisjahbana, A. S., \& Manning, C. (2006). Labour market dimensions of poverty in Indonesia. Bulletin of Indonesian Economic Studies, 42(2), 235-261.

Asian Development Bank. (2006). Country Gender Assessment: Indonesia. Manila.

Atwell, A. (2006). The Impact of A Leadership Training Program on School Based Management and School Community Action in Praya Barat Daya, Lombok, Indonesia. University of Southern Queensland, Australia.

Badan Pusat Statistik. (2011). Keadaan Angkatan Kerja di Indonesia Agustus 2011. Jakarta: Badan Pusat Statistik.

Badan Pusat Statistik. (2017). Keadaan Angkatan Kerja Di Indonesia Agustus 2017. Jakarta: Badan Pusat Statistik.

Badan Pusat Statistik. (2018). Indeks Pembangunan Manusia 2018. Jakarta: Badan Pusat Statistik.

Blackburn, S. (2004). Women and the state in modern Indonesia. Cambridge: Cambridge University Press.

Booth, A. (2016). Women, Work and the Family: Is Southeast Asia Different? Economic History of Developing Regions, 31(1), 167-197. https://doi.org/10.1080/20780389.2015.1132624

Brockman, J. D. (2014, April). The services sector is the fastest-growing sector in the Indonesian economy. International Trade Forum. Retrieved from http://www.tradeforum.org/article/Indonesian-services-sectorfinds-its-voice/

Budiatri, A. P. (2016). Perbandingan Peran dan Kinerja Anggota Legislatif Laki-Laki dan Perempuan dalam Proses Legislasi Undang- Undang yang Responsif Gender. Kajian, 16(3), 466-492.

Cabinet Secretariat. (2019). Di Hadapan Para Pemimpin G20, Presiden Jokowi Angkat Isu Pemberdayaan Perempuan. Retrieved October 23, 2020, from Cabinet Secretariat website: https:/setkab.go.id/di-hadapanpara-pemimpin-g20-presiden-jokowi-angkat-isu-pemberdayaan-perempuan/

Cameron, L., Suarez, D. C., \& Rowell, W. (2019). Female Labour Force Participation in Indonesia: Why Has it Stalled? Bulletin of Indonesian Economic Studies, 55(2), 157-192. https://doi.org/10.1080/00074918.2018.1530727

Comola, M., \& De Mello, L. (2009). The determinants of employment and earnings in Indonesia: A multinomial selection approach (No. 690). OECD. https://doi.org/10.1787/18151973

Cueva Beteta, H. (2006). What is missing in measures of women's empowerment? Journal of Human Development, $7(2), 221-241$.

Cunningham, W. V., \& Villaseñor, P. (2016). Employer Voices, Employer Demands, and Implications for Public Skills Development Policy Connecting the Labor and Education Sectors. The World Bank Research Observer, 31(1), 102-134. https://doi.org/10.1093/wbro/lkv019

Debebe, G. (2009). Transformational learning in women's leadership development training. Advancing Women in Leadership Journal, 29.

Dewi, Y., \& Rachmawati, R. (2014). Leadership development experiences of women leaders in state-owned enterprises in Indonesia. The South East Asian Journal of Management, 167-181.

Dhewy, A. (2018). Women and The Care Economy. Jurnal Perempuan, 23(4).

Djajadiningrat-Nieuwenhuis, M. (1987). Ibuism and priyayization: Path to power? In E. Locher-Scholten \& A. Niehof (Eds.), Indonesian women in focus: Past and present notions (Vol. 127, p. 43). Dordrecht: Foris Publications.

Elson, D. (2000). The progress of women: Empowerment and economics. The Progress of the World's Women. New York: UNIFEM.

Elson, Diane, \& Sharp, R. (2010). Gender-responsive budgeting and women's poverty. Adelaide: Edward Elgar.

Feridhanusetyawan, T., Aswicahyono, H., \& Perdana, A. A. (2001). The male-female wage differentials in Indonesia. Economics Working Paper Series, 59, 1-22.

Fernandez, A., Della Giusta, M., \& Kambhampati, U. S. (2015). The intrinsic value of agency: The case of Indonesia.

Endah Prihatiningtyastuti/Regional Women's Economic Participation: A Systematic-based Review of Structural Economic Transformation in Indonesia 
World Development, 70, 92-107.

Folbre, N. (2006). Measuring care: Gender, empowerment, and the care economy. Journal of Human Development, 7(2), 183-199.

Folbre, N. (2008). Reforming care. Politics E Society, 36(3), 373-387.

Ford, M. (2017). Indonesia: Middle-class complicity and state failure to provide care. In Women, Work and Care in the Asia-Pacific (pp. 71-86). London: Routledge.

Ford, M. (2018). Investing in women: Indonesia country context paper. Retrieved from https://investinginwomen.asia/wp-content/uploads/2018/01/Investing-in-Women-Indonesia-Country-

Context-Paper-1-1.pdf

Ford, M., \& Parker, L. (2008). Women and work in Indonesia (Vol. 5). London: Routledge.

Geertz, H. (1961). The Javanese Family - A Study of Kinship and Socialization. New York: The Free Press of Glencoe, Inc.

Gender Institute. (2013). Advice to Indonesian Government on the draft bill on Gender Equality.

Halim, D., Johnson, H., \& Perova, E. (2017). Could childcare services improve women's labor market outcomes in Indonesia? Washington, DC.

Hartl, M. (2009). Technical and vocational education and training (TVET) and skills development for poverty reduction - do rural women benefit? Workshop on Gaps, Trends and Current Research in Gender Dimensions of Agricultural and Rural Employment: Differentiated Pathways out of Poverty.

Hayati, E. N., Högberg, U., Hakimi, M., Ellsberg, M. C., \& Emmelin, M. (2011). Behind the silence of harmony: risk factors for physical and sexual violence among women in rural Indonesia. BMC Women's Health, 11(1), 52.

Hermawati, T. (2007). Budaya Jawa dan kesetaraan gender. Jurnal Komunikasi Massa, 1(1), 18-24.

Hillman, B. (2018). The limits of gender quotas: women's parliamentary representation in Indonesia. Journal of Contemporary Asia, 48(2), 322-338.

ILO. (2013). Labour and social trends in Indonesia 2013: Reinforcing the role of decent work in equitable growth. Jakarta.

ILO. (2018). World Employment and Social Outlook Trends 2018: Employment in Asia-Pacific continues to grow but often remains of poor quality. Retrieved October 23, 2020, from International Labour Organization website: https://www.ilo.org/asia/media-centre/news/WCMS_615872/lang--en/index.htm

JICA. (2011). Country Gender Profile: Indonesia. Tokyo. Retrieved from https://www.jica.go.jp/english/our_work/thematic_issues/gender/background/pdf/e10ind.pdf

Kabeer, N. (1999). Resources, agency, achievements: Reflections on the measurement of women's empowerment. Development and Change, 30(3), 435-464.

Kabeer, N. (2012). Women's economic empowerment and inclusive growth: labour markets and enterprise development. International Development Research Centre, 44(10), 1-70.

Kevane, M., \& Levine, D. I. (2000). The changing status of daughters in Indonesia.

Kompas. (2014). "Nawa Cita", 9 Agenda Prioritas Jokowi-JK. Retrieved October 20, 2020, from Kompas website: https://nasional.kompas.com/read/2014/05/21/0754454/.Nawa.Cita.9.Agenda.Prioritas.Jokowi-JK

Kusujiarti, S. (1997). Antara ideologi dan transkrip tersembunyi: Dinamika hubungan gender dalam masyarakat Jawa. In I. Abdullah (Ed.), Sangkan Paran Gender. Yogyakarta: Pustaka Pelajar.

Lockley, A., Marcoes, L., Nugroho, K., \& Boang-Manalu, A. G. (2019). Women's Collective Action for Empowerment in Indonesia. Jurnal Perempuan, 24(1), 13-26.

Matsumomoto, M. (2016). Women's Employment in Indonesia Gaining More from Structural Transformation. India: Sage Publication.

Mayoux, L. (1998). Women's Empowerment and Micro-Finance Programmes Approaches, Evidence and Ways Forward.

McCarthy, J. F., Steenbergen, D., Acciaioli, G., Baker, G., Lucas, A., Rambe, V., \& Warren, C. (2014). 10 Dilemmas of participation: the National Community Empowerment Program. Reg. Dyn. a Decentralized Indones, 501, 233.

Minister of National Development Planning. (2017). The National Medium Term Development Plan 2015-2019. Jakarta: Minister of National Development Planning.

Moser, C. (1994). Women, Human Settlements and Housing. London/New York: Tavistock Publications.

Nansereko, S. C. (2010). A gender perspective to value chain analysis for wood-furniture industry upgrading: a case of Jepara, Central Java, Indonesia. Copenhagen University, Denmark.

Newberry, J. (2014). Women against children: Early childhood education and the domestic community in postSuharto Indonesia. TRaNS: Trans-Regional and-National Studies of Southeast Asia, 2(2), 271-291.

Nilan, P. (2008). Youth transitions to urban, middle-class marriage in Indonesia: faith, family and finances. Journal of Youth Studies, 11(1), 65-82.

Noerdin, E., Aripurnama, S., \& Muchtar, Y. (2007). Decentralization as a Narrative of Opportunity for Women in Indonesia. Jakarta: Women Research Institute. 
OHCHR. (2014). Reproductive and Care Functions: From Caring to Sharing. Geneva. Retrieved from https://www.ohchr.org/Documents/Issues/Women/WG/ESL/BackgroundPaper5.pdf

Omar, S. (2014). Marriage in Islam: life partnership or discriminatory family set up? An analysis of some protective legal and moral Shariah provisions for women with special reference to Surah An-Nisa. An Analysis of Some Protective Legal and Moral Shariah Provisions for Women with Special Reference to Surah An-Nisa (September 5, 2014).

Platt, M. (2018). Migration, Moralities and Moratoriums: Female Labour Migrants and the Tensions of Protectionism in Indonesia. Asian Studies Review, 42(1), 89-106. https://doi.org/10.1080/10357823.2017.1408571

Presiden Republik Indonesia. (2019). Pidato Kenegaraan Presiden Republik Indonesia Dalam Rangka Hut Ke-74 Proklamasi Kemerdekaan Republik Indonesia. Jakarta: Presiden Republik Indonesia. Retrieved from https://aptika.kominfo.go.id/wp-content/uploads/2019/08/Pidato-Kenegaraan-Jokowi-2019.pdf

Presiden Republik Indonesia. Peraturan Presiden Nomor 114 Tahun 2020 tentang Strategi Nasional Keuangan Inklusif. , (2020). Presiden Republik Indonesia.

Prihatiningtyastuti, E. (2018). The effects of gender mainstreaming policy on women, focusing on drinking water provision in Indonesia. University of Western Australia.

Pyle, J. L. (2006). Globalization and the increase in transnational care work: The flip side. Globalizations, 3(3), 297315.

Robinson, K. (2008). Gender, Islam, and democracy in Indonesia. London: Routledge.

Schaner, S., \& Das, S. (2016). Female labor force participation in Asia: Indonesia country study. Asian Development Bank Economics Working Paper Series, (474).

Schüler, D. (2006). The uses and misuses of the Gender-Related Development Index and Gender Empowerment Measure: a review of the literature. Journal of Human Development, 7(2), 161-181.

Setyonaluri, D. (2013). Women Interrupted: Determinants of Women's Employment Exit and Return in Indonesia. Bulletin of Indonesian Economic Studies, 50(3), 485-486.

Siahaan, A. Y. (2003). The politics of gender and decentralization in Indonesia. Budapest: Open Society Institute.

Sigiro, A. N. (2018). Care Economy and the Burden of Housewives' Work in Indonesia. Jurnal Perempuan, 23(4), 249-258.

Sitepu, M. (2017). Mother's Day: The Indonesian economy can be more prosperous if the mothers do not stop working. Retrieved October 20, 2020, from BBC Indonesia website: https://www.bbc.com/indonesia/indonesia-42428508

Sohn, K. (2015). Gender discrimination in earnings in Indonesia: A fuller picture. Bulletin of Indonesian Economic Studies, 51(1), 95-121.

Statista. (2019). Literacy rate in Indonesia from 2012 to 2019, by age group. Retrieved October 23, 2020, from Statista website: https:/www.statista.com/statistics/703103/literacy-rate-by-age-group-in-indonesia/

Sullivan, N. (1994). Masters and managers: A study of gender relation in urban Java. New South Wales: Allen and Unwin.

Sullivan, Norma. (1991). Gender and Politics in Indonesia. In M. Stivens (Ed.), Why Gender Matters in Southeast Asian Politics. Australia: Centre of Southeast Asian Studies Monash University Aristoc Press.

Suryakusuma, J. (2011). Ibuisme negara: Konstruksi sosial keperempuanan orde baru. Depok: Komunitas Bambu.

Suwarno, P. (2019). Equality in Education and Employment for Sustainable Development of Diverse Indonesia: Enhancing Equal Opportunity, Volunteerism, and Philanthropy. 1st Non-Formal Education International Conference, 1-8.

Tambunan, T. (2004). Globalisasi dan perdagangan internasional. Jakarta: Ghalia Indonesia.

Tandos, R. (2017). Protection and Empowerment for Indonesian Female Migrant Domestic Workers. State University of New York.

Tjandraningsih, I. (2018). Working, Housekeeping, and Organizing: The Patriarchal System in Three Women's Living Spaces. Jurnal Perempuan, 23(4), 227-233.

Tjandraningsih, Indrasari. (2000). Gendered work and labour control: Women factory workers in Indonesia. Asian Studies Review, 24(2), 257-268.

UNDP. (2016). Human Development Report 2016 Human Development for Everyone Briefing note for countries on the 2016. New York.

United Nation. (2013). World Population Ageing 2013. New York. Retrieved from https://www.un.org/en/development/desa/population/publications/pdf/ageing/WorldPopulationAgeing20 13.pdf

Utomo, A. J. (2012). Women as secondary earners: Gendered preferences on marriage and employment of university students in modern Indonesia. Asian Population Studies, 8(1), 65-85. 
Van Eeuwijk, P. (2006). Old-age vulnerability, ill-health and care support in urban areas of Indonesia. Ageing $\mathcal{E}$ Society, 26(1), 61-80.

White, B. N. F., \& Hastuti, E. L. (1980). Different and unequal: male and female influence in household and community affairs in two West Javanese villages. Bogor.

Widarti, D. (2004). Supporting potential women exporters: The case of Indonesia. In A Case Study for Supporting Potential Women Exporters CTI. Ottawa: APEC.

World Bank. (2012). Toward Gender Equality in East Asia and the Pacific A Companion to the World Development Report. Washington. http://documents1.worldbank.org/curated/en/270511468246373406/pdf/734380PUB0Box30ward0gender0eq uality.pdf

World Bank. (2016). Profortion of Seats held by Women in National Parliaments (\%). Retrieved October 20, 2020, from World Bank website: https://data.worldbank.org/indicator/SG.GEN.PARL.ZS

Yuliantini, L. (2018). Measuring the Autonomy of Female Family Heads in Savings and Loans Activities at a Microfinance Institution. Jurnal Perempuan, 23(4), 215-226.

Yumarni, T., \& Amaratunga, D. (2015). Resource capability for local government in mainstreaming gender into disaster risk reduction: evidence from Indonesia. Genewa. Retrieved from http://eprints.hud.ac.uk/id/eprint/27348/

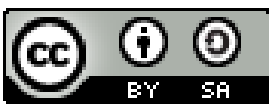

(C) 2020 by the authors. Submitted for possible open access publication under the terms and conditions of the Creative Commons Attribution (CC BY SA) license (https://creativecommons.org/licenses/by-sa/3.0/). 